\title{
IDENTIFIKASI ANTIBODI SPESIFIK Toxoplasma gondii PADA WANITA DI KOMUNITAS PECINTA SUGAR GLIDER INDONESIA (KPSGI) KOTA MAKASSAR
}

\author{
${ }^{1}$ Dzikra Arwie \\ ${ }^{2}$ Rahmat Aryandi \\ IProgram Studi DIII Analis Kesehatan Stikes Panrita Husada Bulukumba \\ ${ }^{2}$ Program Studi DIII Analis Kesehatan Stikes Panrita Husada Bulukumba
}

\begin{abstract}
Alamat Koresponden:
Program Studi DIII Analis Kesehatan

Sekolah Tinggi Ilmu Kesehatan Panrita Husada

Bulukumba, 04132514721

Hp. 085213453935

Email: dzikraarwie88@gmail.com
\end{abstract}




\begin{abstract}
ABSTRAK
Penelitian ini dilatar belakangi oleh cukup banyaknya minat masyarakat untuk memelihara hewan peliharan seperti sugar glider tetapi efek negatif dari hewan ini dapat menyebabkan penyakit zoonosis seperti toksoplasmosis yang disebabkan oleh parasit Toxoplasma gondii. Namun keberadaan antibodi spesifik Toxoplasma gondii terhadap pecinta sugar glider belum diketahui dengan pasti. Penelitian ini bertujuan untuk mengidentifikasi antibodi spesifik Toxoplasma gondii pada wanita di komunitas Pecinta Sugar Glider Indonesia (KPSGI) kota Makassar. Penelitian merupakan observasi laboratorik dengan teknik analisa kualitatif dengan subjek penelitian adalah wanita di komunitas pecinta sugar glider (KPSGI) kota Makassar. Dari 10 sampel yang diambil dengan teknik purposive sampling diperoleh $40 \%$ sampel wanita yang didalam tubuhnya terdapat antibodi spesifik Toxoplasma gondii.
\end{abstract}

\title{
Kata Kunci : Antibodi Spesifik, Toxoplasma gondii, Sugar Glider
}

\begin{abstract}
This research is motivated by quite a lot of public interest in maintaining pet animals such as sugar gliders but the negative effects of these animals can cause zoonotic diseases such as toxoplasmosis caused by the parasite Toxoplasma gondii. However, the presence of Toxoplasma gondii specific antibodies against sugar glider lovers is not known with certainty. This study aims to identify specific Toxoplasma gondii antibodies in women in the Makassar Sugar Glider Indonesia (KPSGI) Lovers community. The study was a laboratory observation with qualitative analysis techniques with the research subjects being women in the sugar glider (KPSGI) lover community in Makassar. Of the 10 samples taken by purposive sampling technique, $40 \%$ of female samples were obtained in the body with Toxoplasma gondii specific antibodies.
\end{abstract}

Keywords: Specific Antibody, Toxoplasma gondii, Sugar Glider 


\section{PENDAHULUAN}

Indonesia merupakan negara berkembang dengan tingkat pencemaran biologi yang cukup tinggi, seperti cacing, virus, bakteri, jamur, dan parasit lainnya. Kematian akibat penyakit infeksi $51 \%$ disebabkan oleh HIV/AIDS, tuberkulosis, dan malaria, 20\% disebabkan Neglected Tropical Diseases (NTD), dan 29\% disebabkan infeksi lainnya. Penyakit infeksi yang diakibatkan oleh parasit kurang mendapat perhatian dari masyarakat karena pada umumnya tidak mengancam jiwa sehingga masyarakat cenderung mengabaikan dan mulai menyadari ketika penyakit sudah memasuki fase kronis. Penyakit infeksi yang masih endemis namun belum memperoleh respon yang signifikan dari masyarakat salah satunya adalah toksoplasmosis (Wahyu, 2007).

Toksoplasmosis merupakan penyakit infeksi yang disebabkan oleh parasit protozoa Toxoplasma gondii. Toxoplasma gondii berasal dari bahasa latin toxon yang artinya adalah busur dan plasma yang berarti bentuk, atau dapat diartikan sebagai bentuk yang serupa dengan busur. Penemu dari Toxoplasma gondii adalah Nicolle dan Manceaux pada tahun 1908 yang menemukan keberadaan protozoa tersebut pada limpa dan hati hewan pengerat yang sedang diamati (Chahaya, 2010).

$$
\text { Menurut Hendri }
$$

diperkirakan 30 sampai $60 \%$ penduduk dunia terinfeksi Toxoplasma gondii. Sekitar 30\% penduduk Amerika Serikat positif terhadap pemeriksaan serologis yang menujukkan pernah terinfeksi dan lebih dari $45 \%$ wanita berusia produktif (20-30 tahun) terpapar parasit tersebut meski tubuh telah memiliki sistem imunitas. Infeksi ini tersebar di seluruh dunia, dimana manusia sebagai hospes perantara. Prevalensi toxoplasmosis di beberapa daerah di Indonesia antara 2 sampai $51 \%$. Berdasarkan survey data frekuensi Toxoplasmosis pada penduduk di beberapa daerah di Indonesia, yaitu di Kalimantan Barat sebesar 3\%, Sulawesi Tenggara $8 \%$, Sulawesi Utara $8 \%$, Sumatra Utara 9\%, Surabaya 9\%, Jawa Tengah 10\%, Jawa Barat $20 \%$. Kalimantan Selatan 31\% dan Makassar $60 \%$.

Angka kejadian Toksoplasmosis di Indonesia ditunjukkan dengan adanya anti Toxoplasma gondii, pada manusia 2-63\%, pada kucing $35-73 \%$, babi $11-36 \%$, kambing 11-61\%, anjing 75\% dan pada ternak lain kurang dari $10 \%$ (Gandahusada dkk, 2003). Penularan toksoplasmosis pada manusia dapat diperoleh secara aktif (dapatan) maupun 
secara pasif (kongenital). Infeksi dapatan terjadi ketika manusia mengonsumsi makanan yang terinfeksi ookista Toxoplasma gondii atau dari kondisi lingkungan yang tercemar oleh ookista yang berasal dari hewan peliharaan (Iskandar et al., 2010).

Sugar Glider merupakan mamalia berdarah panas dan merupakan hewan yang dapat dijadikan peliharaan karena memiliki sifat sosial komunal. Menjadikan hewan sebagai peliharaan memiliki banyak keuntungan, namun disisi lain dapat juga mendatangkan dampak negatif bagi pemeliharanya. Diantaranya, jika hewan peliharaan tersebut kesehatan dan kebersihan lingkungannya tidak terjaga dengan baik, hewan tersebut dapat menjadi perantara berbagai penyakit zoonosis yang dapat menyebabkan penyakit toksoplasmosis (Seitz, 2009 dan Chandra, 2001).

Pada umumnya manusia yang menderita toksoplasmosis tidak menunjukkan gejala klinis spesifik dan sulit untuk dibedakan dengan penyakit lainnya. tetapi bila diuji melalui serum pasien menunjukkan prevalensi yang tinggi. Hal ini diperkirakan kerentanan manusia terhadap infeksi atau karena adanya sistem kekebalan tubuh manusia yang dikenal dengan imunoglobulin. Sehingga diperlukan diagnosis laboratorium untuk mengetahui keberadaan parasit Toxoplasma gondii melalui sistem kekebalan tubuh manusia yang terbentuk. Oleh karena itu diagnosis laboratorium sebaiknya dilakukan melalui uji serologi (Siregar, 2012 dan Subekti, 2004).

Tujuan utama dari uji serologi adalah melihat reaksi antibodi spesifik Toxoplasma gondii dalam tubuh penderita dengan mengukur imunoglobulin $\mathrm{G}$ anti Toxoplasma gondii yang terbentuk. (Hanafiah et al., 2010 dan Subekti, 2004). Immunoglobulin $\mathrm{G}$ atau $\mathrm{IgG}$ merupakan antibodi yang melimpah dan ditemukan pada semua cairan dalam tubuh manusia, kadarnya akan meningkat jika tubuh terserang infeksi. IgG dan melindungi tubuh manusia terhadap infeksi baik yang disebakan oleh parasit, bakteri, maupun virus (Chahaya, 2010 dan Mohamad, 2001).

Infeksi ini kemungkinan besar terjadi apabila manusia sering malakukan kontak langsung terhadab binatang yang terinfeksi dengan Toxoplasma gondii. Namun, permasalahan yang timbul hingga saat ini adalah keberadaan antibodi spesifik Toxoplasma gondii terhadap pecinta sugar glider belum diketahui dengan pasti. Berdasarkan latar belakang di atas maka penulis tertarik untuk melakukan penelitian mengenai 
identifikasi antibodi spesifik Toxoplasma gondii pada wanita di komunitas Pecinta Sugar Glider Indonesia (KPSGI) kota Makassar.

\section{METODE}

\section{Jenis Penelitian}

Jenis penelitian ini adalah observasional deskriptif dengan teknik analisa kualitatif yang bertujuan untuk mengidentifikasi keberadaan antibodi Toxoplasma gondii pada wanita di komunitas pecinta sugar glider (KPSGI) di kota Makassar.

\section{Alat Dan Bahan Penelitian}

1. Alat

Alat yang digunakan dalam penelitian ini adalah Rak tabung, spoit, Tourniquet, tabung EDTA, centrifuge, mikropipet, tip, slide, rotator, box sampel

2. Bahan

Serum, kapas alkohol swap, kit aglutinasi lateks untuk deteksi antibodi spesifik Toxoplasma gondii.

\section{Prosedur Penelitian}

\section{Metode}

Metode pemeriksaan dalam penelitian ini adalah metode aglutinasi latex.

\section{Prinsip}

Partikel latex dilapisi dengan antigen Toxoplasma gondii. Serum yang mengandung antibodi Toxoplasma gondii dengan konsentrasi yang cukup dicampur dengan reagen latex Toxo maka aglutinasi akan terjadi. Tidak terjadi aglutinasi jika tidak terdapat antibodi Toxoplasma gondii dalam serum atau jika konsentrasi Toxoplasma gondii dibawah batas sensitivitas 4IU/ml. HumaTex Toxo

\section{Prosedur Kerja}

a. Pra analitik

Alat dan bahan yang akan digunakan disiapakan, cuci tangan, sterilkan daerah yang akan dilakukan pemeriksaan.

\section{b. Analitik}

Latex reagen, positif control, negative control dan sampel diletakkan pada suhu kamar, kemudian sampel dipipet sebanyak $50 \mu 1$ dan diletakkan pada lingkaran slide pertama, satu tetes control positif pada lingkaran slide kedua dan satu tetes control negatif pada lingkaran slide ketiga, kemudian ditambahkan satu tetes reagen latex pada masing lingkaran slide, masing-masing dihomogenkan stick pengaduk dan digoyangkan selama 3 menit.

c. Pasca Analitik

Interpretasi hasil :

Positif $(+)=$ Bila terbentuk aglutunasi pada spesimen pasien

Negatif $(-)=$ Bila tidak terbentuk aglutunasi pada spesimen pasien

\section{HASIL PENELITIAN}

Sebanyak 10 subjek yang merupakan pecinta sugar glider telah 
dilibatkan dalam penelitian ini dan tentunya telah memenuhi kriteria inklusi. Berikut disajikan data mengenai hasil identifikasi antibodi spesifik Toxoplasma gondii pada wanita di komunitas Pecinta Sugar Glider Indonesia (KPSGI) kota Makassar.

Hasil identifikasi antibodi spesifik Toxoplasma gondii dapat dilihat pada Tabel 1.

Berdasarkan tabel 1, dari 10 sampel yang diperiksa diperoleh 4 sampel menunjukkan hasil positif $\mathrm{IgG}$ Toxoplasma gondii dengan persentase $40 \%$.

\section{PEMBAHASAN}

Penelitian ini merupakan penelitian observasional deskriptif dengan rancang studi cross sectional. Penelitian dilakukan dalam satu waktu untuk meneliti paparan dan outcome. Penelitian ini mengambil populasi dari Komunitas Pecinta Sugar Glider Indonesia (KPSGI) yang berada di kota Makassar. Jumlah sampel yang digunakan adalah 10 responden. Kriteria inklusi yang telah ditetapkan adalah responden memelihara sugar glider diatas 3 bulan dan kriteria eksklusi adalah peneliti memelihara hewan vertebrata lainnya seperti kucing, anjing, sapi, kerbau, monyet, unggas, dan kambing. Kriteria tersebut ditujukan untuk menghindari bias penelitian yang berpotensi menyebabkan toksoplasmosis pada responden. Pengumpulan data penelitian dilakukan melalui metode wawancara serta pengambilan sampel darah untuk uji serologi kadar Imunoglobulin $\quad \mathrm{G} \quad(\mathrm{IgG})$ anti toksoplasmosis.

Sampel darah yang diambil dari responden sebanyak $5 \mathrm{ml}$ kemudian dilanjutkan dengan pengujian laboratorium di Klinik GG kota Makassar pada bulan November 2018. Identifikasi antibodi spesifik Toxoplasma gondii yaitu dengan uji aglutinasi latek menggunakan Pastorex Toxo Kit (Bio-Rad, France). Prosedur pengujian dilakukan dengan mengikuti prosedur yang telah ditetapkan produsennya. Secara umum, serum yang berasal dari darah yang telah dicentrifuge sebelumnya diteteskan pada permukaan kartu dan dicampur dengan larutan dapar pengencer serta suspensi latek yang telah dilapisi antigen Toxoplasma gondii. Volume serum, larutan dapar pengencer dan supensi latek berlapis antigen adalah sebanding, yaitu masing-masing sekitar $20 \mu \mathrm{L}$. Selanjutnya serum dan suspensi latek dihomogenisasi menggunakan stik plastik dan kemudian di goyang di atas rotator selama 7-10 menit. Reaksi positif apabila terjadi aglutinasi latek seperti butiran pasir, sehingga sampel dapat 
dinyatakan positif toksoplasmosis.

Adapun jika tidak terjadi aglutinasi maka sampel dinyatakan negatif toksoplasmosis. (Surbekti dan Kusumaningtyas, 2011).

Tabel 1 menggambarkan kejadian toksoplasmosis pada 10 responden pemelihara sugar glider yang dtandai dari hasil positif IgG Toxoplasma gondii sebanyak 4 sampel dengan persentase 40\% dan hasil negatif IgG Toxoplasma gondii sebanyak 6 sampel dengan persentase $60 \%$. Penyebaran Toxoplasma gondii melalui binatang peliharaan seperti sugar glider yang merupakan hospes perantara. Penyebaran ini dapat terjadi akibat kebersihan serta kesehatan sugar glider yang tidak terjaga dengan baik, kandang yang kotor, serta tidak mencuci tangan setelah memegang hewan sugar glider tersebut sehingga bentuk ookista Toxoplasma gondii dapat tertelan. Penularan toksoplasmosis pada manusia dapat diperoleh melalui infeksi dapatan ataupun infeksi kongenital. Pada infeksi dapatan, manusia dapat terinfeksi bila memakan makanan yang tercemar oleh ookista dari kotoran kucing yang positif toksoplasmosis ataupun menghirup ookista yang telah mencemari lingkungan.

Penularan Toxoplasma gondii juga dapat terjadi melalui kegiatan transfusi darah yang mengandung takizoit (trofozoit), transplantasi organ atau cangkong hati yang terdapat takizoit ataupun kista, serta kecelakaan laboratorium yang menyebabkan Toxoplasma gondii masuk ke dalam tubuh (Chahaya, 2010; Iskandar, 2010).

Toxoplasma gondii yang masuk ke dalam tubuh akan direspon oleh tubuh sebagai antigen yang dapat mengganggu kesehatan tubuh sehingga tubuh akan merespon antigen tersebut dengan membentuk antibodi. Antibodi yang terbentuk pertama kali yaitu kelas immunoglobulin $\mathrm{M} \quad$ (IgM antiToxoplasma gondii) yang akan terbentuk setelah satu minggu pasca Toxoplasma gondii masuk dalam tubuh dan mencapai puncaknya setelah 1-2 bulan dan akan turun setelah 4 bulan. Sedangkan IgG anti- Toxoplasma gondii terbentuk dalam tubuh manusia setelah 2-3 bulan setelah infeksi pertama dan akan terus mengalami peningkatan hingga kadar titer maksimal setelah 6 bulan hingga 1 tahun kemudian turun secara perlahan dan menetap pada kadar rendah seumur hidup. (Gandahusada, 2008; Chandra, 2001).

Pemeriksaan kadar IgG untuk deteksi kejadian toksoplasmosis lebih disarankan apabila dibandingkan dengan IgM. Pemeriksaan laboratorium pada IgM tidak dapat digunakan untuk menegakkan diagnosis kejadian toksoplasmosis karena 
hasil tersebut dapat berupa positif palsu sehingga tidak cukup kuat untuk dijadikan acuan diagnosis. Uji serologi $\operatorname{IgG}$ anti toksoplasmosis lebih dianjurkan karena kadar IgG anti toksoplasmosis bertahan lebih lama di dalam tubuh manusia bila dibandingkan dengan IgM. Penguatan akurasi diagnosis dapat dilakukan melalui pemeriksaan menggunakan metode lainnya guna menentukan stadium keparahan dan organ yang diserang oleh Toxoplasma gondii (Subekti, 2004, Robert \& Janovy, 2001).

Dampak yang dikhawatirkan oleh infeksi toksoplasma ini adalah infeksi pada ibu hamil yang dapat menularkan kepada bayinya pada saat masih dalam kandungan, janin tersebut belum memiliki sistem pertahan tubuh yang kuat sehingga dapat membahayakan kesehatan janin seperti abortus maupun cacat bawaan. Hartono (2006) melakukan penelitian pada tahun 1993-1994 pada wanita yang mengalami keguguran di Rumah Sakit Cipto Mangunkusumo dan Rumah Sakit Hasan Sadikin dan diperoleh hasil $51,48 \%$ positif terinfeksi Toxoplasma gondii. Iskandar (2008) melakukan penelitian pada 52 orang yang mengalami keguguran di Kota Surabaya dan diperoleh hasil sekitar $46,1 \%$ terjangkit toksoplasmosis.
Upaya perawatan yang dilakukan pemelihara sugar glider sangat memiliki peran yang sangat penting dalam mengurangi potensi infeksi Toxoplasma gondii seperti kebiasaan untuk membersihkan tubuh hewan peliharaannya, menjaga jenis makanan yang dikonsumsi, serta membersihkan habitat sugar glider. Penggunaan desinfektan untuk membersihkan lingkungan mampu mengurangi jumlah ookista yang berada di lingkungan.

\section{KESIMPULAN dan SARAN}

Kesimpulan penelitian ini adalah dari 10 sampel yang diperiksa diperoleh 4 sampel $(40 \%)$ terdapat antibodi spesifik Toxoplasma gondii Pada wanita yang berada di Komunitas Pecinta Sugar Glider Indonesia (KSPGI) kota Makassaar.

\section{DAFTAR PUSTAKA}

1. Chahaya, I. 2010. Epidemiologi Toxoplasma gondii. Palembang: USU library.

2. Chandra, G. 2001. Toksoplasma gondii: Aspek Biologi, Epidemiologi, Diagnosis, dan Penatalaksanaannya. Medika, 5(27), pp. 297-304.

3. Hanafi ah, M., Mufti Kamaruddin, Wisnu Nurcahyo \& Winaruddin, 2010. Studi Infeksi Toksoplasmosis pada Manusia dan Hewan di Banda Aceh. 
Jurnal Kedokteran Hewan, Volume 4 No. 2, pp. 87-92.

4. Iskandar, T. 2010. Tinjauan tentang Toksoplasmosis pada Manusia dan Hewan. Wartazoa, 8(2), pp. 58-63.

5. Mohamad, S. 2001. Biokimia Darah. Jakarta: Widya Medika.

6. Seitz, R. 2009. Arboprotozoae. Transfus. Med. Hemother, Volume 36, pp. 8-31.

7. Siregar, R. Y. 2012. Gambaran Kejadian Toxoplasmosis di
Yogyakarta. Buletin Laboratorium Veteriner, Volume 12 (2), pp. 14-21.

8. Subekti, D.T. and E. Kusumaningtyas. 2011. Comparison of serological test for toxoplasmosis using Immunostick Assay, ELISA and Latex Agglutination Test. JITV 16(3): 224-233.

9. Wahyu, S.T. 2007. Neglected Tropical Diseases (NTDs), Why do We Neglect Them?. Bandung: National Congress of PETRI. 
Tabel 1 identifikasi antibodi spesifik Toxoplasma gondii

\begin{tabular}{|c|c|c|c|c|c|}
\hline \multirow[b]{2}{*}{$\mathrm{NO}$} & \multirow{2}{*}{$\begin{array}{c}\text { KODE } \\
\text { SAMPEL }\end{array}$} & \multirow[b]{2}{*}{ UMUR } & \multirow[b]{2}{*}{ Jenis Kelamin } & \multicolumn{2}{|c|}{ HASIL } \\
\hline & & & & $(+)$ & $(-)$ \\
\hline 1 & Sampel A & 19 Thn & Perempuan & & $(-)$ \\
\hline 2 & Sampel B & 29 Thn & Perempuan & $(+)$ & \\
\hline 3 & Sampel C & 27 Thn & Perempuan & & $(-)$ \\
\hline 4 & Sampel D & 25 Thn & Perempuan & & $(-)$ \\
\hline 5 & Sampel E & 29 Thn & Perempuan & $(+)$ & \\
\hline 6 & Sampel F & 19 Thn & Perempuan & & $(-)$ \\
\hline 7 & Sampel G & 32 Thn & Perempuan & $(+)$ & \\
\hline 8 & Sampel H & 19 Thn & Perempuan & & $(-)$ \\
\hline 9 & Sampel I & 27 Thn & Perempuan & & $(-)$ \\
\hline 10 & Sampel J & 25 Thn & Perempuan & $(+)$ & \\
\hline \multicolumn{4}{|c|}{ Jumlah } & 4 & 6 \\
\hline \multicolumn{4}{|c|}{ Persentase } & $40 \%$ & $60 \%$ \\
\hline
\end{tabular}

